\title{
Cannabidiol prevents lipopolysaccharide-induced sickness behavior and alters cytokine and neurotrophic factor levels in the brain
}

\author{
Pedro Augusto Lopes Tito ${ }^{1,2}$ Túlio Cézar de Souza Bernardino ${ }^{1,2} \cdot$ Paula Maria Quaglio Bellozi ${ }^{1,2}$. \\ Maria Carolina Machado da Silva ${ }^{2}$. Aline Silva de Miranda ${ }^{3}$. Érica Leandro Marciano Vieira ${ }^{1,4}$. \\ Fabrício A. Moreira ${ }^{1,2} \cdot$ András Palotás ${ }^{5,6,7}$. Antônio Carlos Pinheiro de Oliveira ${ }^{1,2} \cdot$ Helton José Reis ${ }^{1,2}$ (1)
}

Received: 23 March 2021 / Revised: 18 June 2021 / Accepted: 18 June 2021 / Published online: 3 July 2021

(c) Maj Institute of Pharmacology Polish Academy of Sciences 2021

\begin{abstract}
Background Major depressive disorder (MDD) affects millions of people worldwide. While the exact pathogenesis is yet to be elucidated, the role of neuro-immune signaling has recently emerged. Despite major advances in pharmacotherapy, antidepressant use is marred by limited efficacy and potential side effects. Cannabidiol (CBD), a phytocannabinoid, exerts antidepressant-like effects in experimental animals. This study investigated the impact of CBD on sickness behavior (SB), a measure of depressive-like response, and neuro-immune changes induced by lipopolysaccharides (LPS) in mice.

Methods Socially isolated rodents were administered with LPS to trigger SB. and treated with CBD or its vehicle. Animals were submitted to forced swimming test, to evaluate depressive-like behavior, and to open field test, to evaluate locomotory activity. Immediately after behavioral analyses, animals were euthanized and had their hypothalamus, prefrontal cortex and hippocampus dissected, to proceed neurotrophins and cytokines analyses. ELISA was used to detect IL-1 $\beta$, BDNF and NGF; and cytometric beads array to measure IL-2, IL-4, IL-6, IFN- $\gamma$, TNF- $\alpha$ and IL-10 levels.

Results CBD effectively prevented SB-induced changes in the forced swim test without altering spontaneous locomotion. This phytocannabinoid also partially reversed LPS-evoked IL-6 increase in both the hypothalamus and hippocampus. In addition, CBD prevented endotoxin-induced increase in BDNF and NGF levels in the hippocampus of SB animals.

Conclusions Apparently, CBD prevents both behavioral and neuro-immunological changes associated with LPS-induced $\mathrm{SB}$, which reinforces its potential use as an antidepressant which modulates neuroinflammation. This opens up potentially new therapeutic avenues in MDD.
\end{abstract}

Keywords Cannabidiol $\cdot$ Cytokines $\cdot$ Forced swim test $\cdot$ Lipopolysaccharide $\cdot$ Neurotrophic factor $\cdot$ Sickness behavior

\section{Introduction}

Major depressive disorder (MDD) is one of the most frequent psychiatric disorders [1]. It affects over 322 million people of all ages, and is the leading cause of disability worldwide [2]. According to the World Health Organization

Antônio Carlos Pinheiro de Oliveira

antoniooliveira@icb.ufmg.br

$\triangle$ Helton José Reis

heltonjr@icb.ufmg.br

1 Neuroscience Program, Universidade Federal de Minas Gerais, Belo Horizonte, MG, Brazil

2 Neurofar Lab, Departamento de Farmacologia, ICB, Universidade Federal de Minas Gerais, Av. Antônio Carlos 6627, Belo Horizonte, MG 31270-901, Brazil
$[3,4]$, MDD is one of the most damaging diseases of the society, since it decreases the quality of life, increases the use of health services and consumes enormous public health costs [5]. Roughly half of the patients do not experience complete remission following initial treatment. Of these, $30-50 \%$ do not respond to any treatment at all [4, 6-9].

\footnotetext{
3 Departamento de Morfologia, ICB, Universidade Federal de Minas Gerais, Belo Horizonte, Brazil

4 Interdisciplinary Laboratory of Medical Investigation, Faculdade de Medicina, Universidade Federal de Minas Gerais, Belo Horizonte, MG, Brazil

5 Asklepios-Med, Szeged, Hungary

6 Eszterházy Károly University, Eger, Hungary

7 Kazan Federal University, Kazan, Russia
} 
Several inflammatory mediators may represent biomarkers for MDD, such as C reactive protein, interleukin (IL)-1 $\beta$, IL-2 and IL-6, interferon (IFN)- $\gamma$ and tumor necrosis factor (TNF) [10-12], most of them being increased in patients with MDD [13, 14]. Administration of lipopolysaccharide (LPS), a component of the bacterial cell wall and an important activator of the innate immune response, is used to understand the role of the inflammation in the pathogenesis of the MDD [15, 16]. LPS administration can induce both sickness behavior (SB) and depressive-like behavior in humans and rodents [16]. Both models are capable of mimicking behavioral alterations present in the MDD, such as melancholic lethargy, social disinterest and anhedonia [16, 17]. Importantly, the main difference between these models is the time, once sickness behavior appears 2 to $6 \mathrm{~h}$ postLPS, and the depressive-like behavior appears $24 \mathrm{~h}$ postLPS [17].

Among several compounds under investigation as novel treatment options for MDD, cannabidiol (CBD) has received particular attention. CBD is a phytocannabinoid, a natural compound extracted from Cannabis sativa which, in contrast with the major phytocannabinoid, delta-9-tertrahydrocannabinol (THC), has no psychotomimetic or other deleterious effects [18-20]. Whereas THC acts mainly as an agonist at the cannabinoid receptors $\mathrm{CB}_{1}$ and $\mathrm{CB}_{2}, \mathrm{CBD}$ seems to exert multiple effects in the brain, indirectly facilitating the endocannabinoid (eCB) system [21-23] and activating serotonin (5-HT) $1 \mathrm{~A}$ receptors $[24,25]$.

In the eCB system, CBD has low affinity for the CB1 agonist site [22] and greater affinity for the antagonist site [23], acting as a negative allosteric modulator, decreasing the binding of agonists such as $\Delta 9$-THC or 2-AG [21]. CBD acts as an inverse agonist with low affinity to $\mathrm{CB}_{2}$, although this mechanism may not represent a pharmacological relevance [23]. In addition, CBD also acts as an antagonist of the orphan receptor coupled to the G 55 protein (GPR55), an allosteric modulator of the opioid mu and delta receptors, an agonist of the transient receptors of the cation channel subfamily V (TRPV1) [26] and an agonist of the activated peroxisome proliferating gamma receptor (PPAR $\gamma$ ) [27]. Finally, CBD also exerts modulation of neurotransmission by AEA, since it is an inhibitor of the AEA transporter and the FAAH enzyme [26], and by adenosine, since CBD inhibits the reuptake of this neurotransmitter [28]. Although these are possible mechanisms mediated by CBD, the pharmacology of CBD is complex, due to the other target and to the sites of action in the brain (see reviews: $[27,29,30]$ ).

The eCB system is affected in depressive disorders, since depressed patients present decreased serum levels of eCBs and increased expression of $\mathrm{CB}_{1}$ in the prefrontal cortex in post mortem studies $[12,31]$. There are still few studies with the use of CBD in patients with MDD or in animal models. CBD reduced immobility in forced swim test
(FST) in Swiss mice, an effect that was mediated by the $5-\mathrm{HT}_{1 \mathrm{~A}}$ receptor [32]. Moreover, CBD reduced in vivo synthesis of IFN- $\gamma$ in lymph node and serum concentration of TNF in LPS-exposed mice [33], as well as reduced IL-6, TNF, COX-2 and iNOS in a hypoxic-ischemic model [34], which was mediated by adenosine $\mathrm{A}_{2 \mathrm{~A}}$ receptors. However, in other conditions, CBD may also reveal pro-inflammatory effects. CBD enhanced the pulmonary inflammation induced by LPS, by increasing the mRNA production of some cytokines, such as TNF and IL-6 [35]. Besides, a $C$. sativa fraction enriched with $\mathrm{CBD}$ increased the expression of IL-6, IL-8 and CCL2 in macrophages treated with phorbol-12-myristate-13-acetate, a fraction enriched with CBD increased the expression of IL-6, IL-8 and CCL2 [36]. In addition, the drug also increased IFN- $\gamma$ and IL- 2 production in splenocytes depending on the magnitude of the stimulus [37]. CBD also demonstrates a pro-inflammatory effect in epithelial cells, monocytes, and fibroblasts, by increasing the levels of inflammatory mediators such as IFN- $\gamma$, IL- $1 \beta$, IL-6, IL-8 and MCP-1 [38]. Finally, CBD also increased IL-6 levels in rats with persistent inflammatory pain [39].

Inflammation is a key component in MDD pathophysiology, and there are behavioral and biochemical similarities between this disorder and the SB model. Thus, a drug that affects both neurotransmitters and inflammatory pathways may be suitable for the treatment of this condition. In this sense, CBD may act not only in the cannabinoid system, but also modulate the production of inflammatory mediators. However, as described above, this drug reveals paradoxical effects depending on the model of inflammation. Therefore, it is important to evaluate the effect of CBD on behavioral and biochemical alterations in a model of SB induced by LPS administration.

\section{Materials and methods}

\section{Drugs}

Cannabidiol (THC Pharm GmbH, Frankfurt, Germany) was homogenized on the day of the experiment in $5 \%$ Tween ${ }^{\circledR}$ 80 in saline $(0.9 \% \mathrm{NaCl})$. LPS (Sigma, E. coli 0111:B4) $0.83 \mathrm{mg} / \mathrm{ml}$ was prepared immediately before administration in sodium chloride $0.9 \%$. The volume of $10 \mathrm{ml} / \mathrm{kg}$ of the drugs were used to inject in the animals. Thus, the doses of CBD used in the present experiment were 30,10 and $3 \mathrm{mg} /$ $\mathrm{kg}$. The dose of LPS was $0.83 \mathrm{mg} / \mathrm{kg}$. The CBD doses were chosen according to the studies of Zanelati et al. [32], since this group has also investigated the properties of CBD in another animal model of depression. Furthermore, the LPS dose was chosen according to O'Connor et al. and Wickens et al. [40, 41]. 


\section{Animals}

Experiments were conducted using C57B1/6J male mice (8-12 weeks of age) obtained from Bioterism Center of Institute of Biological Sciences/UFMG. Animals were kept in PIV cages ( 5 animals per cage before the isolating period), under controlled room temperature $\left(25^{\circ} \mathrm{C}\right)$ and $12 \mathrm{~h}: 12 \mathrm{~h}$ light-dark cycle, with free access to food and water. All the procedures used in this study were institutionally approved under protocol number 78/2014 (approval date: May 26, 2015) by the Ethic Committee on Animal Use of Federal University of Minas Gerais.

\section{Behavioral tests}

\section{Sickness behavior model}

SB is a set of psychological and behavioral changes associated with a febrile and neuroendocrine response to an infectious challenge $[42,43]$ and has great similarities with depressive disorder changes [43]. The main changes are lethargy, loss of concentration, social disinterest, anhedonia, drowsiness, anorexia and weight loss [43]. To induce $\mathrm{SB}, 10-12$-week-old animals were submitted to social isolation for 10 days, in individual cages. While isolated, animals were also kept under controlled room temperature $\left(25^{\circ} \mathrm{C}\right)$ under $12 \mathrm{~h}: 12 \mathrm{~h}$ light-dark cycle, with free access to food and water. After this period, animals received an i.p. injection with vehicle or drug (CBD $30 \mathrm{mg} / \mathrm{kg}$ ) in the left iliac fossa and $1 \mathrm{~h}$ later an i.p. injection of $0.9 \%$ saline or LPS (Sigma, E. coli $0.83 \mathrm{mg} / \mathrm{kg}$ ) in the right iliac fossa. LPS was prepared immediately before administration in sodium chloride $0.9 \%$ [44]. The reason for administering CBD $1 \mathrm{~h}$ before LPS is that we analysed SB $6 \mathrm{~h}$ after LPS injection, a time frame that would hamper a post treatment to evaluate the therapeutic effect of the drug.

The treatment schedule used was based on previous studies that reported the relation between the sickness behavior induced by the LPS and the increase in the inflammatory cytokines levels. Cytokines, such as TNF and IL-6, which mediate the development of sickness behavior, are increased $2 \mathrm{~h}$ after LPS administration, reaching maximum concentration within $6 \mathrm{~h}[17,40,45]$.

\section{Forced swim test}

Animals received an i.p. injection with vehicle or CBD $(30 \mathrm{mg} / \mathrm{kg})$ in the left iliac fossa and $1 \mathrm{~h}$ later an i.p. injection of $0.9 \%$ saline or LPS $(0.83 \mathrm{mg} / \mathrm{kg})$ in the right iliac fossa. Six hours after saline and LPS injection, animals were submitted to a forced swim test (FST). The test was recorded for $6 \mathrm{~min}$. The forced swim apparatus was $200 \mathrm{~mm}$ height and $180 \mathrm{~mm}$ diameter. Apparatus was filled until $150 \mathrm{~mm}$ height with water at $25^{\circ} \mathrm{C}$ [46]. Experiments were recorded and analyzed by a blind experimenter. The last $4 \mathrm{~min}$ of the test were used to analyse the immobility time.

\section{Open field test}

An independent group of animals received an i.p. injection with vehicle or drug (CBD $30 \mathrm{mg} / \mathrm{kg}$ ) in the left iliac fossa and $1 \mathrm{~h}$ later an i.p. injection of $0.9 \%$ saline or LPS $(0.83 \mathrm{mg} / \mathrm{Kg})$ in the right iliac fossa. Six hours after saline and LPS injection, animals were introduced in the center of the open field and left to explore the apparatus for $5 \mathrm{~min}$. The open field apparatus had $30 \mathrm{~cm}$ diameter. Experiments were recorded and analyzed by a blind experimenter. The total distance travelled was calculated with the ANY-maze software version 4.99 .

\section{Analyses of neurotrophins and cytokine}

Immediately after the behavioral test, animals were euthanized by cervical dislocation, and had their hypothalamus (HT), prefrontal cortex (PFC) and hippocampus (HP) dissected. Tissues from animals submitted to the FTS were homogenized in $200 \mu \mathrm{l}$ of a buffer containing protease inhibitors [ $\mathrm{NaCl}(0.4 \mathrm{M})$; Tween $20(0.05 \%)$; Bovine Serum Albumin (BSA) (0.5\%); phenylmethylsulfonyl fluoride (PMSF) (0.1 mM); benzethonium chloride $(0.1 \mathrm{mM})$; EDTA $(10 \mathrm{mM})$; aprotinin (20 IU) in PBS]. Total proteins were measured by Bradford method.

Enzyme Linked Immunosorbent Assay (ELISA) was used to measure IL-1 $\beta$, BDNF and NGF (kits DuoSet ${ }^{\circledR}$ R\&D Systems), in accordance with the procedures described by the manufacturer. Briefly, $100 \mu \mathrm{l}$ solution containing $1 \times$ PBS and an appropriate concentration of the specific capture antibody were added to a 96-well plate, which remained in contact with the plate for $18 \mathrm{~h}$ at $4{ }^{\circ} \mathrm{C}$. Subsequently, plates were washed 4 times with a washing buffer in a plate washer (BioTek ${ }^{\mathrm{TM}}$ ELx50 ${ }^{\mathrm{TM}}$ Microplate Strip Washer). The plate was incubated with a blocking solution (1\% BSA in PBS) for $2 \mathrm{~h}$, washed 4 times and the cytokine standards in known concentrations and samples were added to the reaction, followed by $18 \mathrm{~h}$ of incubation at $4{ }^{\circ} \mathrm{C}$. The plate was washed again and incubated with $100 \mu \mathrm{l}$ of the detection antibody for $2 \mathrm{~h}$. Afterwards, a new series of washes and a solution containing streptavidin linked to peroxidase was added to the plate. After $30 \mathrm{~min}$ of incubation at room temperature, the plate was washed again and the substrate buffer containing ortho-phenylenediamine (OPD-Sigma) and $\mathrm{H}_{2} \mathrm{O}_{2}$ (Merck) was added. The reaction was stopped with $50 \mu \mathrm{l}$ of hydrochloric acid at a concentration of $1 \mathrm{M}$. The OPD oxidation product was detected by colorimetry in an ELISA plate reader at a wavelength of $490 \mathrm{~nm}\left(\right.$ BioTek $^{\mathrm{TM}} \mathrm{ELx} 800^{\mathrm{TM}}$ Absorbance Reader). 
Cytometric Bead Array (CBA) mouse (Th1/Th2/Th17, BD) was used to detect IL-2, IL-4, IL-6, IFN- $\gamma$, TNF- $\alpha$ and IL-10, as previously described [44]. Briefly, after preparing the capture spheres using the kit reagents, $25 \mu \mathrm{l}$ of the supernatant of the preparations were added to $25 \mu \mathrm{l}$ of solution containing capture spheres in a 96-well plate and incubated protected from light for $2 \mathrm{~h}$. After incubation, the plate was centrifuged for $5 \mathrm{~min}$ at $200 \mathrm{~g}$ and its supernatant was aspirated and discarded. One hundred $\mu$ of washing buffer was added to the plate and it was submitted to 2 cycles of 5 min of centrifugation at $200 \mathrm{~g}$. One hundred $\mu$ l of wash buffer was added and mixed for $2 \mathrm{~min}$ at $1100 \mathrm{rpm}$. This content was transferred to $15 \mathrm{ml}$ conical polypropylene tubes for reading by the BD FACSCanto ${ }^{\circledR}$ cytometer with laser reading capacity for $488,532,633$ or $635 \mathrm{~nm}$ ranges and capable of distinguishing fluorescence between 576, 660 and $>680 \mathrm{~nm}$. All the procedures followed the manufacturer's instructions.

\section{Statistical analysis}

Statistical analysis was performed using the statistical software GraphPad Prism 8.0 and Statistic. Data were submitted to the Kolmogorov-Smirnov test for normality evaluation and Grubbs' test and ESD method for identification of extreme values. Data were analyzed by one-way analysis of variance (ANOVA) or two-way ANOVA, if applicable, followed by Bonferroni test for variables with parametric distribution. Data are presented as the mean \pm standard error of the mean (SEM). The level of significance was set at $p<0.05$.

\section{Results}

\section{CBD prevented SB-induced changes in the FST}

We first performed a dose-response curve to evaluate the CBD effects in basal immobility time. In the absence of LPS, CBD (3, 10 and $30 \mathrm{mg} / \mathrm{kg})$ did not change the immobility time in FST [data not shown; $n=8$ ]. Since none of the tested doses changed this behavior, the $30 \mathrm{mg} / \mathrm{kg}$ dose was chosen to be tested in animals treated with LPS, based on previously published data that evaluated the antidepressant/ anxiolytic-like effects of CBD [32, 47-49].

Regarding the immobility time, two-way ANOVA revealed a significant effect of LPS $\left(F_{1,48}=30.95\right.$; $p<0.0001)$, a significant effect of CBD treatment $\left(F_{1,48}=9.394 ; p=0.0036\right)$, as well as a significant LPS $\times$ CBD interaction $\left(F_{1,48}=15.57 ; p=0.0003\right)$. Posthoc analysis showed that LPS significantly increased the immobility time, which was prevented by the treatment with
CBD $30 \mathrm{mg} / \mathrm{kg}$ (Fig. 1A). CBD per se did not influence the immobility time.

In the open field test, two-way ANOVA indicated a significant effect of LPS $\left(F_{1,36}=38.13 ; p<0.0001\right)$, with no significant effect of CBD treatment $\left(F_{1,36}=0.01898 ; p=0.8912\right)$ and no significant LPS $\times$ CBD interaction $\left(F_{1,36}=0.002392\right.$; $p=0.9613)$. Post-hoc analysis showed that LPS decreased locomotor activity. However, CBD pretreatment did not influence the total travelled distance induced by LPS. There was no influence of CBD treatment in the total travelled distance in the absence of LPS (Fig. 1B).

\section{CBD induced varied effects on cytokines levels}

We performed a dose-response curve to evaluate the CBD effects in cytokines levels in the hypothalamus, PFC and hippocampus from naïve animals (Supplementary Table 1). One-way ANOVA followed by Bonferroni post-hoc test showed that the lower dose of CBD $(3 \mathrm{mg} / \mathrm{kg})$ increased the IL-1 $\beta$, IFN- $\gamma$, IL-4 and IL-6 levels in the PFC $(p<0.05)$.

A FST
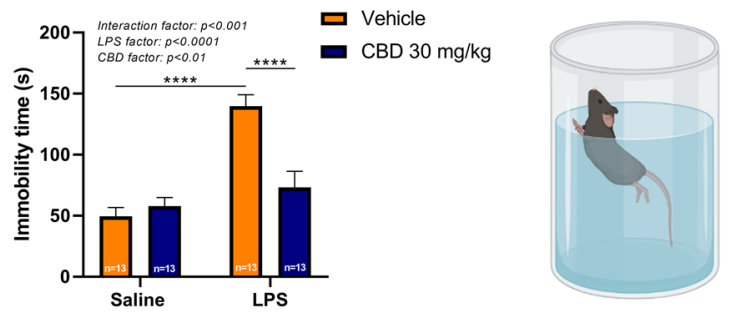

B Open Field Test
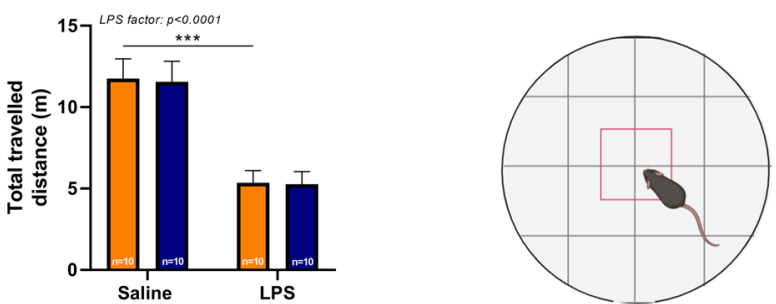

Fig. 1 Effect of CBD treatment on sickness behavior and locomotion. Effect of CBD (30 mg/kg, i.p.) and LPS $(0.83 \mathrm{mg} / \mathrm{kg}$, i.p.) in the forced swim test (FST). Bar graphs of immobility time from saline + vehicle $\quad(n=13), \quad$ saline + CBD $\quad(n=13), \quad$ LPS + vehicle $(n=13)$ and LPS + CBD $(n=13)$ groups and representative image of the FST (A). Effect of CBD (30 mg/kg, i.p.) and LPS $(0.83 \mathrm{mg} / \mathrm{kg}$, i.p.) in the open field test (OFT) and representative image of the OFT. Bar graphs of total distance travelled from saline + vehicle $(n=10)$, saline $+\mathrm{CBD} \quad(n=10), \quad \mathrm{LPS}+$ vehicle $\quad(n=10)$ and LPS + CBD $(n=10)$ groups (B). Results are expressed as mean \pm SEM. $* * * p<0.001$ and $* * * * p<0.0001$ (Two-way ANOVA followed by the Bonferroni). $N=10-13$ in each group 
Hippocampus

A

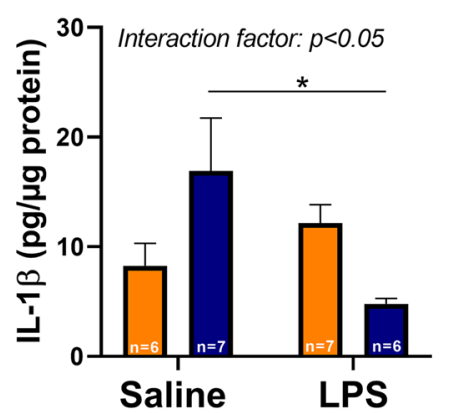

D

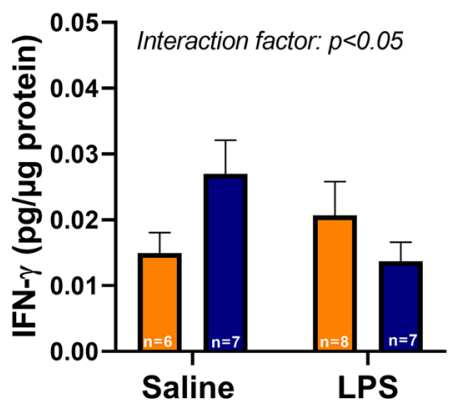

G

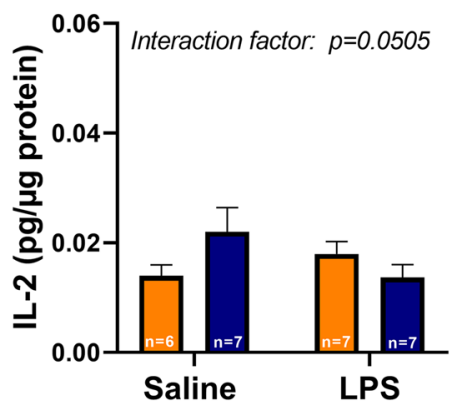

J

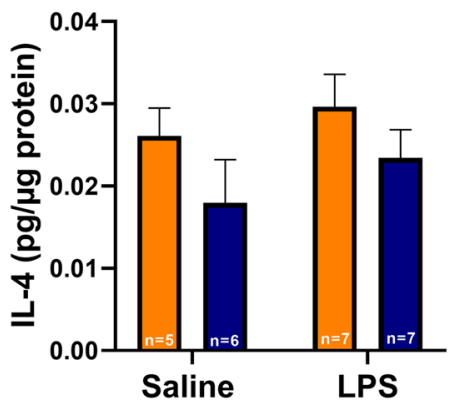

PFC

B

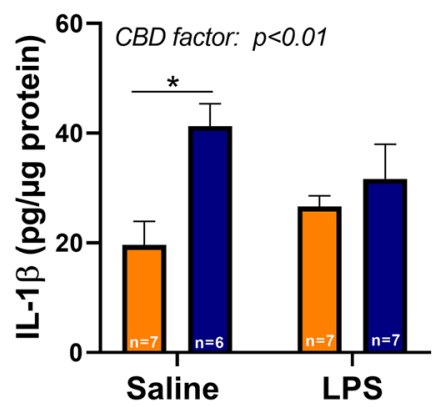

E

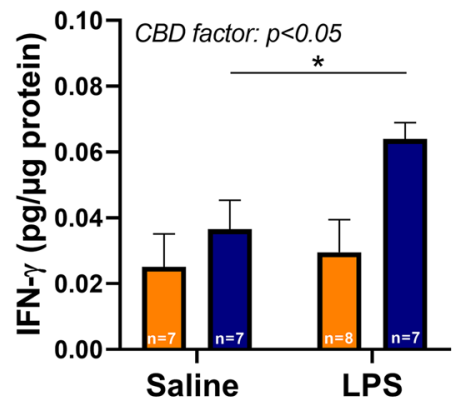

H

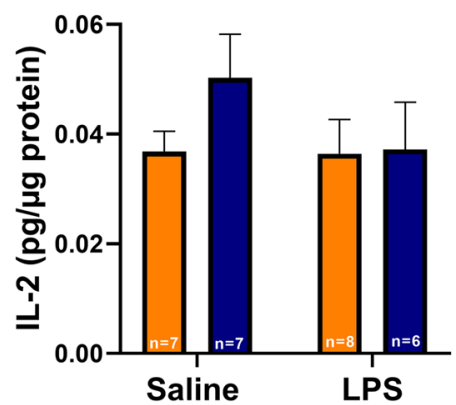

K

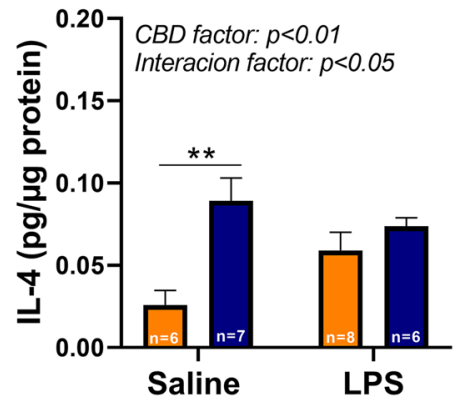

Hypothalamus

C

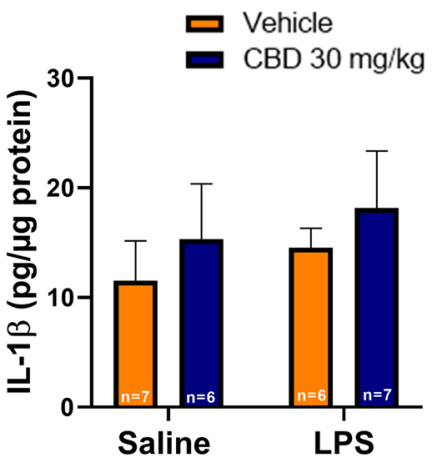

F

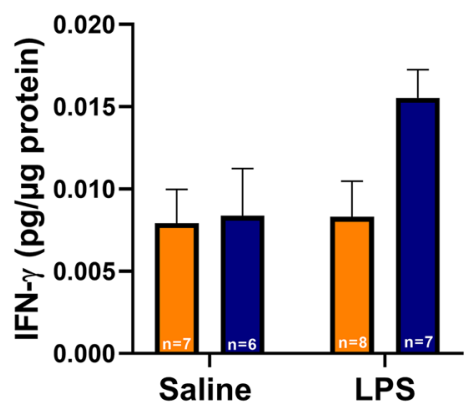

I

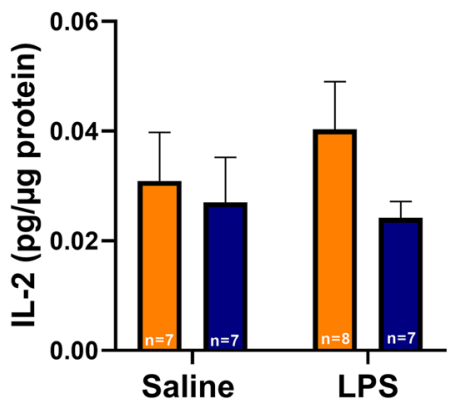

L

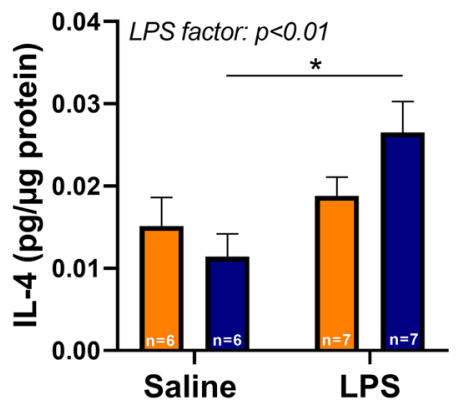

Fig. 2 Effect of CBD treatment in brain cytokines. Effect of CBD (30 mg/kg, i.p.) and LPS (0.83 mg/kg, i.p.) on the levels of brain cytokines. Bar graphs of IL-1 $\beta$ (A-C), IFN- $\gamma(\mathbf{D}-\mathbf{F})$, IL-2 (G-I), IL-4 (J-L), IL-6 (M-O), IL-10 (P-R) TNF- $\alpha(\mathbf{S}-\mathbf{U})$ in the hip- pocampus, PFC and hypothalamus, respectively. Results are expressed as mean \pm SEM. $* p<0.05$ and $* * p<0.01$. (Two-way ANOVA followed by the Bonferroni test). $N=6-8$ in each group 


\section{Hippocampus}

M

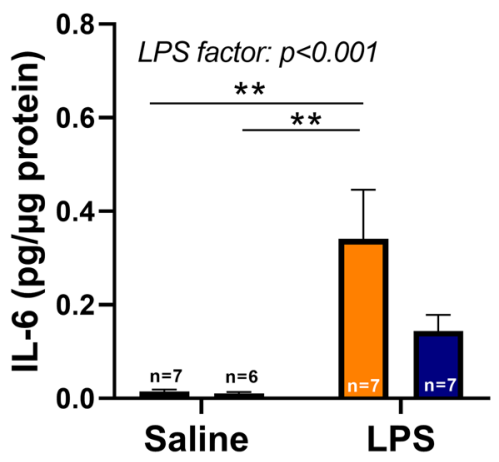

$\mathbf{P}$

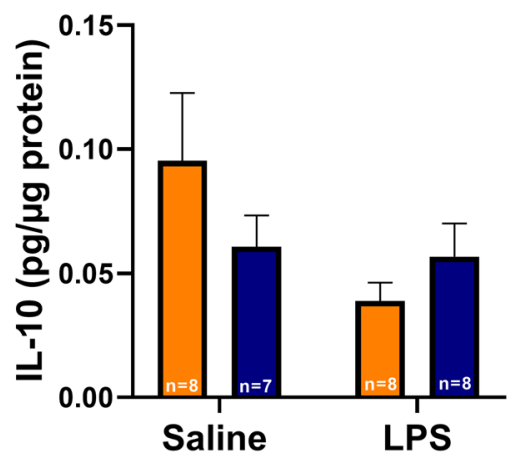

S

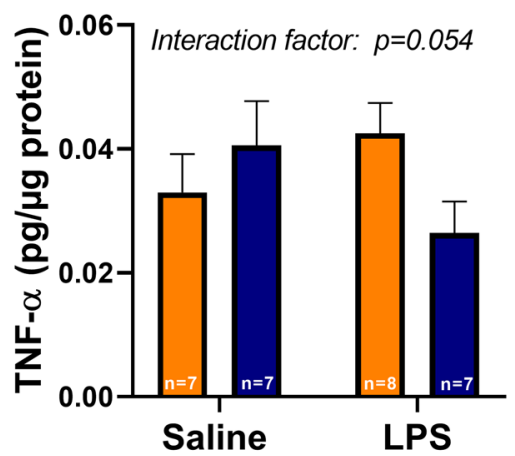

PFC

$\mathbf{N}$

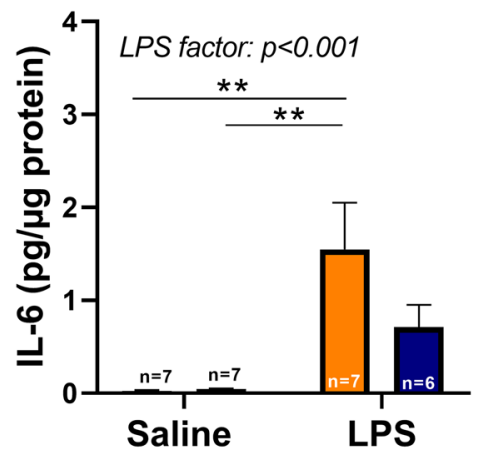

$\mathbf{Q}$

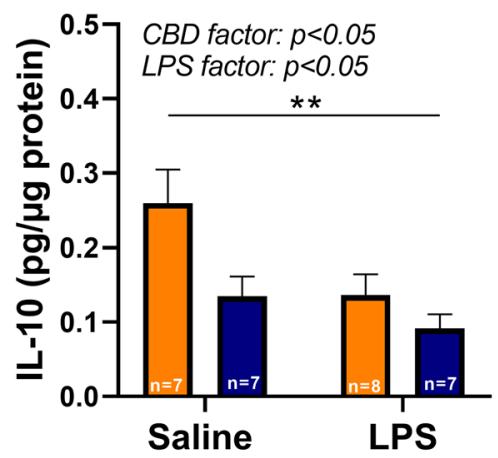

$\mathbf{T}$

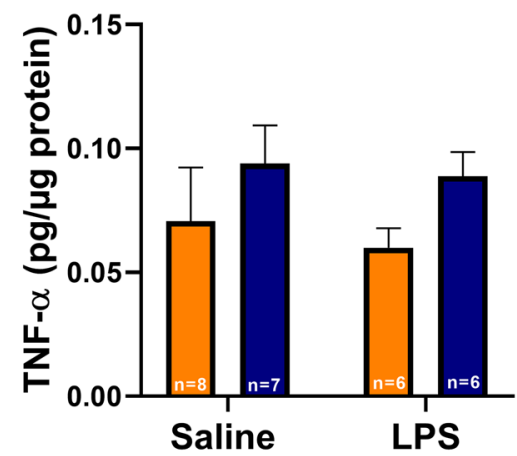

Hypothalamus

0

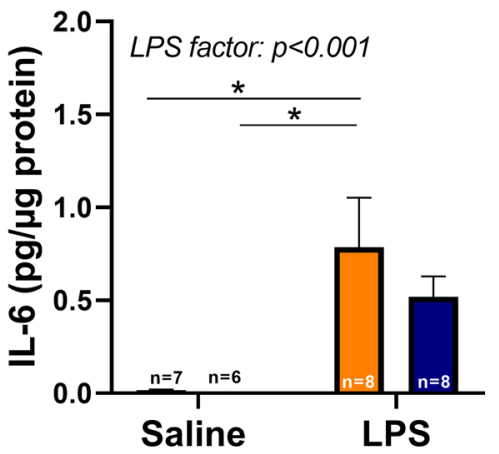

$\mathbf{R}$

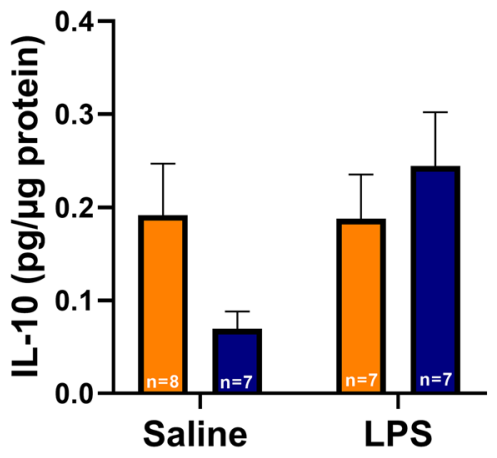

U

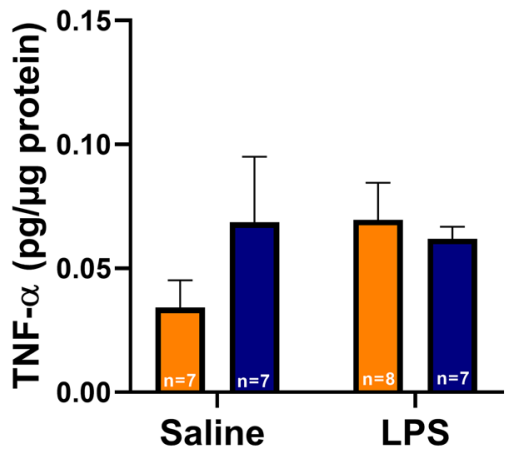

Fig. 2 (continued)

Afterward, we evaluated the cytokines levels from animals treated with LPS $(0.83 \mathrm{mg} / \mathrm{kg})$ and CBD $(30 \mathrm{mg} /$ $\mathrm{kg}$ ). In the hippocampus, two-way ANOVA showed a significant LPS $\times$ CBD interaction for IL- $1 \beta$ and IFN- $\gamma$ levels $(p<0.05)$ (Fig. 2A, D; Table 1), and a strong tendency towards LPS $\times$ CBD interaction for TNF- $\alpha$ and IL-2 levels ( $p=0.0544$ and $p=0.0505$, respectively) (Fig. 2G, S;
Table 1). These results demonstrate that CBD has opposite effects in the animals treated with saline + CBD in comparison with the animals treated with LPS $+\mathrm{CBD}$, since CBD pretreatment increased these cytokines levels in the saline-treated animals, but decreased their levels in LPStreated animals, suggesting an anti-inflammatory effect in this region. 
Table 1 CBD effect on LPS-induced changes on cytokines and neurotrophic factors

\begin{tabular}{|c|c|c|c|c|c|c|c|c|}
\hline \multirow[t]{2}{*}{ Cytokine } & \multirow[t]{2}{*}{ Region } & \multicolumn{4}{|c|}{ Cytokine concentration (pg/mg of total protein) } & \multicolumn{3}{|l|}{ ANOVA } \\
\hline & & $\mathrm{V}+\mathrm{S}$ & $\mathrm{CBD} 30+\mathrm{S}$ & $\mathrm{V}+\mathrm{LPS}$ & CBD $30+$ LPS & $\begin{array}{l}\text { Interaction treatment } \\
\text { vs. SB factor }\end{array}$ & $\begin{array}{l}\text { Treatment factor (V } \\
\text { or CBD 30) }\end{array}$ & $\begin{array}{l}\text { SB factor (S or } \\
\text { LPS) }\end{array}$ \\
\hline \multirow[t]{3}{*}{$\mathrm{IL}-1 \beta$} & HT & $11.6 \pm 3.6$ & $15.3 \pm 5.1$ & $14.6 \pm 1.8$ & $18.2 \pm 5.2$ & $\begin{array}{l}F_{1,22}=0.0003595 \\
p=0.9850\end{array}$ & $\begin{array}{l}F_{1,22}=0.7617 \\
p=0.3922\end{array}$ & $\begin{array}{l}F_{1,22}=0.4755 \\
p=0.4977\end{array}$ \\
\hline & $\mathrm{PFC}$ & $19.6 \pm 4.3$ & $41.25 \pm 4.1$ & $26.7 \pm 1.9$ & $31.7 \pm 6.3$ & $\begin{array}{l}F_{1,23}=3.411 \\
p=0.0777\end{array}$ & $\begin{array}{l}F_{1,23}=8.831 \\
p=0.0068\end{array}$ & $\begin{array}{c}F_{1,23}=0.08075 \\
p=0.7788\end{array}$ \\
\hline & $\mathrm{HC}$ & $8.3 \pm 2.0$ & $16.9 \pm 4.8$ & $12.2 \pm 1.7$ & $4.7 \pm 0.5$ & $\begin{array}{l}F_{1,22}=7.489 \\
p=0.0120\end{array}$ & $\begin{array}{l}F_{1,22}=0.04633 \\
p=0.8316\end{array}$ & $\begin{array}{l}F_{1,22}=1.970 \\
p=0.1744\end{array}$ \\
\hline \multirow[t]{3}{*}{ IFN- $\gamma\left(\times 10^{-3}\right)$} & HT & $7.9 \pm 2.0$ & $12.8 \pm 5.0$ & $8.4 \pm 2.8$ & $15.4 \pm 1.7$ & $\begin{array}{l}F_{1,23}=2.264 \\
p=0.1460\end{array}$ & $\begin{array}{l}F_{1,23}=2.909 \\
p=0.1015\end{array}$ & $\begin{array}{l}F_{1,23}=2.805 \\
p=0.1075\end{array}$ \\
\hline & PFC & $25.2 \pm 10.0$ & $36.5 \pm 8.9$ & $29.5 \pm 9.9$ & $63.9 \pm 4.9$ & $\begin{array}{l}F_{1,26}=1.672 \\
p=0.2073\end{array}$ & $\begin{array}{l}F_{1,26}=6.600 \\
p=0.0163\end{array}$ & $\begin{array}{l}F_{1,26}=3.173 \\
p=0.0866\end{array}$ \\
\hline & $\mathrm{HC}$ & $14.9 \pm 3.0$ & $27.0 \pm 5.0$ & $20.7 \pm 5.1$ & $13.7 \pm 2.9$ & $\begin{array}{l}F_{1,24}=4.755 \\
p=0.0392\end{array}$ & $\begin{array}{l}F_{1,24}=0.3421 \\
p=0.5641\end{array}$ & $\begin{array}{l}F_{1,24}=0.7467 \\
p=0.3961\end{array}$ \\
\hline \multirow[t]{3}{*}{$\operatorname{IL}-2\left(\times 10^{-3}\right)$} & HT & $30.9 \pm 8.8$ & $27.0 \pm 8.2$ & $40.3 \pm 8.7$ & $24.2 \pm 3.0$ & $\begin{array}{l}F_{1,24}=0.5944 \\
p=0.4483\end{array}$ & $\begin{array}{l}F_{1,24}=1.579 \\
p=0.2210\end{array}$ & $\begin{array}{l}F_{1,24}=0.1698 \\
p=0.6839\end{array}$ \\
\hline & PFC & $36.8 \pm 3.7$ & $50.3 \pm 8.0$ & $36.4 \pm 6.3$ & $37.2 \pm 8.5$ & $\begin{array}{l}F_{1,24}=0.8669 \\
p=0.3611\end{array}$ & $\begin{array}{l}F_{1,24}=1.104 \\
p=0.3038\end{array}$ & $\begin{array}{l}F_{1,24}=0.9785 \\
p=0.3324\end{array}$ \\
\hline & $\mathrm{HC}$ & $13.9 \pm 2.0$ & $22.0 \pm 4.4$ & $18.0 \pm 2.2$ & $13.7 \pm 3.4$ & $\begin{array}{l}F_{1,23}=4.261 \\
p=0.0505\end{array}$ & $\begin{array}{l}F_{1,23}=0.3792 \\
p=0.5441\end{array}$ & $\begin{array}{l}F_{1,23}=0.5203 \\
p=0.4780\end{array}$ \\
\hline \multirow[t]{3}{*}{ IL-4 $\left(\times 10^{-3}\right)$} & HT & $15.1 \pm 3.4$ & $11.4 \pm 2.8$ & $18.8 \pm 2.2$ & $26.8 \pm 3.8$ & $\begin{array}{l}F_{1,21}=3.172 \\
p=0.0894\end{array}$ & $\begin{array}{l}F_{1,21}=0.3790 \\
p=0.5448\end{array}$ & $\begin{array}{l}F_{1,21}=8.575 \\
p=0.0080\end{array}$ \\
\hline & PFC & $25.9 \pm 8.8$ & $89.2 \pm 13.9$ & $59.0 \pm 11.0$ & $73.9 \pm 5.2$ & $\begin{array}{l}F_{1,22}=4.595 \\
p=0.0434\end{array}$ & $\begin{array}{l}F_{1,22}=11.81 \\
p=0.0024\end{array}$ & $\begin{array}{l}F_{1,22}=0.6046 \\
p=0.4451\end{array}$ \\
\hline & $\mathrm{HC}$ & $26.1 \pm 3.3$ & $17.9 \pm 5.2$ & $29.6 \pm 3.9$ & $23.4 \pm 23.4$ & $\begin{array}{l}F_{1,21}=0.05642 \\
p=0.8145\end{array}$ & $\begin{array}{l}F_{1,21}=1.179 \\
p=0.2900\end{array}$ & $\begin{array}{l}F_{1,21}=3.010 \\
p=0.0974\end{array}$ \\
\hline \multirow[t]{3}{*}{ IL- $6\left(\times 10^{-3}\right)$} & HT & $16.0 \pm 5.4$ & $3.2 \pm 1.1$ & $785.8 \pm 266.2$ & $519.9 \pm 109.1$ & $\begin{array}{l}F_{1,25}=0.6174 \\
p=0.4394\end{array}$ & $\begin{array}{l}F_{1,25}=0.7486 \\
p=0.3951\end{array}$ & $\begin{array}{l}F_{1,25}=15.96 \\
p=0.0005\end{array}$ \\
\hline & PFC & $26.7 \pm 8.1$ & $43.9 \pm 7.9$ & $1548 \pm 503.6$ & $713.0 \pm 240.4$ & $\begin{array}{l}F_{1,23}=2.267 \\
p=0.1458\end{array}$ & $\begin{array}{l}F_{1,23}=2.087 \\
p=0.1620\end{array}$ & $\begin{array}{l}F_{1,23}=14.97 \\
p=0.0008\end{array}$ \\
\hline & $\mathrm{HC}$ & $15.2 \pm 3.4$ & $10.5 \pm 2.7$ & $340.8 \pm 104.9$ & $143.8 \pm 34.9$ & $\begin{array}{l}F_{1,23}=2.779 \\
p=0.1091\end{array}$ & $\begin{array}{l}F_{1,23}=3.053 \\
p=0.0939\end{array}$ & $\begin{array}{l}F_{1,23}=15.82 \\
p=0.0006\end{array}$ \\
\hline \multirow[t]{3}{*}{ IL-10 $\left(\times 10^{-3}\right)$} & HT & $192.2 \pm 54.9$ & $69.6 \pm 18.5$ & $187.8 \pm 68.3$ & $244.3 \pm 58.0$ & $\begin{array}{l}F_{1,25}=3.451 \\
p=0.0750\end{array}$ & $\begin{array}{l}F_{1,25}=0.4699 \\
p=0.4994\end{array}$ & $\begin{array}{l}F_{1,25}=3.139 \\
p=0.0886\end{array}$ \\
\hline & PFC & $260.0 \pm 44.5$ & $134.7 \pm 26.8$ & $136.4 \pm 28.2$ & $91.4 \pm 19.5$ & $\begin{array}{l}F_{1,24}=1.600 \\
p=0.2181\end{array}$ & $\begin{array}{l}F_{1,24}=7.160 \\
p=0.0132\end{array}$ & $\begin{array}{l}F_{1,24}=6.882 \\
p=0.0149\end{array}$ \\
\hline & $\mathrm{HC}$ & $95.3 \pm 27.4$ & $60.8 \pm 12.6$ & $39.0 \pm 7.3$ & $56.9 \pm 13.3$ & $\begin{array}{l}F_{1,27}=2.330 \\
p=0.1385\end{array}$ & $\begin{array}{l}F_{1,27}=0.2361 \\
p=0.6309\end{array}$ & $\begin{array}{l}F_{1,27}=3.082 \\
p=0.0905\end{array}$ \\
\hline \multirow[t]{3}{*}{ TNF- $\alpha\left(\times 10^{-3}\right)$} & HT & $34.2 \pm 11.0$ & $68.6 \pm 26.4$ & $69.6 \pm 15.0$ & $62.0 \pm 4.8$ & $\begin{array}{l}F_{1,25}=1.664 \\
p=0.2089\end{array}$ & $\begin{array}{l}F_{1,25}=0.6782 \\
p=0.4180\end{array}$ & $\begin{array}{l}F_{1,25}=0.7777 \\
p=0.3862\end{array}$ \\
\hline & PFC & $70.7 \pm 21.6$ & $93.9 \pm 15.4$ & $60.0 \pm 7.8$ & $89.0 \pm 9.6$ & $\begin{array}{l}F_{1,23}=0.03078 \\
p=0.8623\end{array}$ & $\begin{array}{l}F_{1,23}=2.543 \\
p=0.1244\end{array}$ & $\begin{array}{l}F_{1,23}=0.2359 \\
p=0.6318\end{array}$ \\
\hline & $\mathrm{HC}$ & $33.0 \pm 6.2$ & $40.6 \pm 7.2$ & $42.5 \pm 4.9$ & $26.4 \pm 5.1$ & $\begin{array}{l}F_{1,25}=4.074 \\
p=0.0544\end{array}$ & $\begin{array}{l}F_{1,25}=0.5236 \\
p=0.4760\end{array}$ & $\begin{array}{l}F_{1,25}=0.1496 \\
p=0.7022\end{array}$ \\
\hline \multirow[t]{2}{*}{ Neurotrophin } & \multirow[t]{2}{*}{ Region } & \multicolumn{4}{|c|}{ Neurotrophin concentration (pg/mg of total protein) } & \multicolumn{3}{|l|}{ ANOVA } \\
\hline & & $\mathrm{V}+\mathrm{S}$ & $\mathrm{CBD} 30+\mathrm{S}$ & $\mathrm{V}+\mathrm{LPS}$ & CBD $30+$ LPS & $\begin{array}{l}\text { Interaction treatment } \\
\text { vs. SB factor }\end{array}$ & $\begin{array}{l}\text { Treatment factor } \\
\text { (V or CBD 30) }\end{array}$ & SB factor (S or LPS) \\
\hline \multirow[t]{2}{*}{ BDNF } & PFC & $22.7 \pm 3.4$ & $28.5 \pm 4.3$ & $20.6 \pm 1.7$ & $29.0 \pm 4.7$ & $\begin{array}{l}F_{1,19}=0.1273 \\
p=0.7252\end{array}$ & $\begin{array}{l}F_{1,19}=3.884 \\
p=0.0635\end{array}$ & $\begin{array}{l}F_{1,19}=0.05384 \\
p=0.8190\end{array}$ \\
\hline & $\mathrm{HC}$ & $9.9 \pm 1.9$ & $13.2 \pm 2.5$ & $15.0 \pm 1.2$ & $8.1 \pm 1.7$ & $\begin{array}{l}F_{1,16}=7.340 \\
p=0.0155\end{array}$ & $\begin{array}{l}F_{1,16}=0.8593 \\
p=0.3677\end{array}$ & $\begin{array}{l}F_{1,16}=0.0003656 \\
p=0.9850\end{array}$ \\
\hline \multirow[t]{2}{*}{ NGF } & PFC & $26.4 \pm 4.3$ & $39.6 \pm 6.4$ & $25.4 \pm 3.1$ & $34.5 \pm 5.1$ & $\begin{array}{l}F_{1,18}=0.6539 \\
p=0.4293\end{array}$ & $\begin{array}{l}F_{1,18}=7.428 \\
p=0.0139\end{array}$ & $\begin{array}{l}F_{1,18}=0.06861 \\
p=0.7964\end{array}$ \\
\hline & $\mathrm{HC}$ & $10.2 \pm 2.0$ & $16.8 \pm 2.7$ & $23.6 \pm 2.7$ & $11.9 \pm 1.8$ & $\begin{array}{l}F_{1,17}=14.60 \\
p=0.0014\end{array}$ & $\begin{array}{l}F_{1,17}=1.140 \\
p=0.3006\end{array}$ & $\begin{array}{l}F_{1,17}=3.114 \\
p=0.0956\end{array}$ \\
\hline
\end{tabular}

Statistical differences are emphasized in bold font

CBD (30 mg/kg, i.p.) effect on LPS-induced ( $0.83 \mathrm{mg} / \mathrm{kg}$, i.p.) changes on cytokines levels

$N=5-8$ in each group

$V$ vehicle, $S$ saline, $H T$ hypothalamus, $P F C$ prefrontal cortex, $H C$ hippocampus, $C B D$ cannabidiol, $L P S$ lipopolysaccharide, $S B$ sickness behavior 


\section{Hippocampus}

A
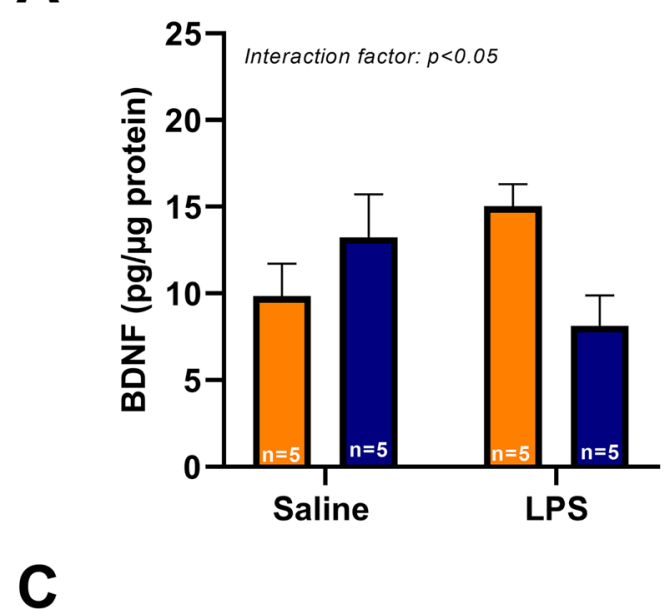

Fig. 3 Effect of CBD treatment in brain neurotrophic factors. Evaluation of CBD (30 mg/kg, i.p.) and LPS (0.83 mg/kg, i.p.) on the levels of brain neurotrophin levels. Bar graphs of $\operatorname{BDNF}(\mathbf{A}, \mathbf{B})$ and NGF

However, in the PFC, two-way ANOVA followed by Bonferroni post-hoc test indicated that CBD pretreatment induced an increase in IL-1 $\beta$ levels without LPS stimulus and in IFN- $\gamma$ levels with LPS stimulus $(p<0.05)$ (Fig. 2B, E; Table 1). Furthermore, two-way ANOVA showed a significant CBD effect and also a significant LPS $\times$ CBD interaction in the IL-4 levels, and Bonferroni post-hoc test indicated that CBD pretreatment increased the IL-4 levels in the saline-treated animals $(p=0.0037)$ (Fig. 2K; Table 1), but had no effect in LPS-treated animals. Besides, regarding the IL-10 levels, two-way ANOVA followed by Bonferroni post-hoc test indicated both CBD and LPS effects, where both treatments decreased the IL-10 levels in this region (Fig. 2Q; Table 1).

In the hypothalamus, two-way ANOVA indicated a significant LPS effect in the IL-4 levels, and the post-hoc test showed a difference between the saline + CBD and
B

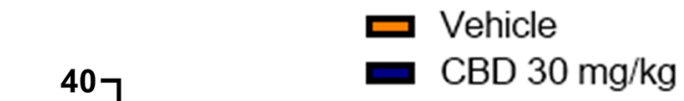

D

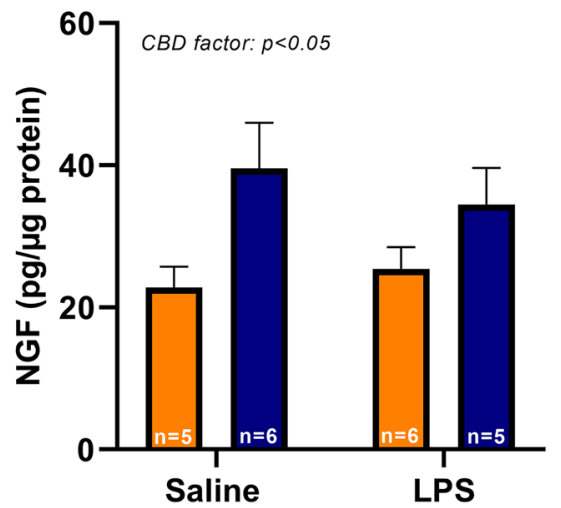

PFC

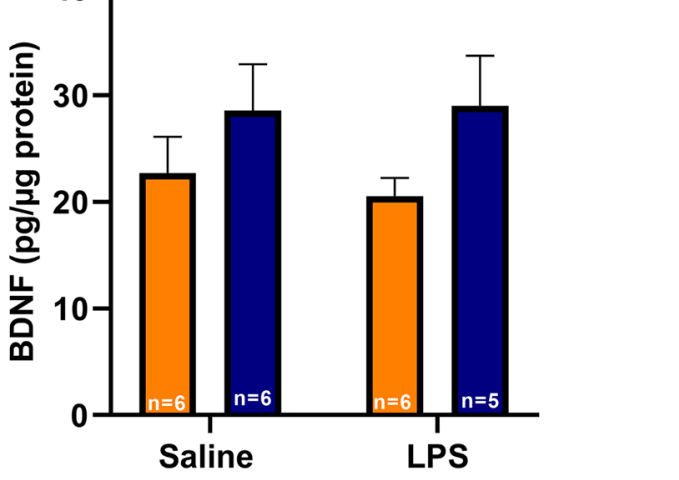

(C, D) in the hippocampus and in PFC, respectively. Results are expressed as mean \pm SEM. $* p<0.05$ (two-way ANOVA followed by the Bonferroni test). $N=5-6$ in each group

LPS + CBD groups $(p=0.0164)$, demonstrating that animals treated with LPS + CBD presented an increase in the IL-4 levels, in comparison with the animals treated with saline + CBD (Fig. 2L; Table 1).

Finally, two-way ANOVA followed by Bonferroni post hoc indicated that LPS significantly increased the IL-6 levels in all regions evaluated (Fig. 2M-O; Table 1). Importantly, CBD partially reduced the levels of this cytokine, since the group treated with the cannabinoid did not differ either from LPS or saline groups. There were no significant changes in the other cytokines levels evaluated (Table 1).

CBD reduced BDNF and prevented the increase in NGF levels in LPS-treated animals. First, we performed the dosage of BDNF and NGF levels in animals in which we performed the dose-response curve to evaluate the CBD effects in these neurotrophin levels. All the data of the BDNF and NGF levels in the PFC and hippocampus of animals treated 
with CBD (3, 10 and $30 \mathrm{mg} / \mathrm{kg}$ ) are described in Supplementary Table 1. One-way ANOVA followed by Bonferroni post-hoc showed that the lowest level of CBD $(3 \mathrm{mg} / \mathrm{kg})$ increased the levels of both neurotrophins in the PFC.

Afterward, we evaluated the neurotrophin levels in brain regions from animals treated with both LPS $(0.83 \mathrm{mg} /$ $\mathrm{kg})$ and CBD $(30 \mathrm{mg} / \mathrm{kg})$. In the hippocampus, two-way ANOVA showed a significant interaction between LPS $\mathrm{x}$ CBD for BDNF and NGF levels ( $p=0.0155$ and $p=0.0014$, respectively), (Fig. 3A and $\mathrm{C}$ ) and a significative restorement of NGF levels in LPS-injected animals treated with CBD $(p=0.0153)$ Besides, in the PFC, two-way ANOVA significantly showed that the CBD treatment has an influence on NGF levels ( $p=0.0139)$ (Fig. 3B).

\section{Discussion}

Despite the major health and socioeconomic impacts associated with the MDD, its pathophysiology remains poorly understood [50-52]. In addition, a number of patients remain refractory to the pharmacological treatments $[4,6-9]$. Thus, there is a demand for new treatments for MDD. In the present study, we demonstrated that CBD revealed antidepressant-like effects that may be associated with the alterations in the levels of inflammatory and neurotrophic factors.

The literature describes several behavioral tests to study depressive-like behavior in animal models, such as FST, tail suspension test and sucrose preference test [53]. The FST is the most commonly used assay, and due its high predictive validity, the FST is also used to investigate potentially new antidepressants $[54,55]$. However, although FST is widely used as a model to evaluate depressive-like behavior, from a broader perspective, this model may be used to evaluate stress coping, that is present in different behavioral disorders [56].

Herein, we observed an increased immobility time in animals submitted to LPS injection, which was prevented by CBD $30 \mathrm{mg} / \mathrm{kg}$. This result corroborates its potential as an antidepressant agent, and strengthens the hypothesis that the drug might reverse the depressive-like behavior, once it has been previously reported that this dose of the cannabinoid also prevented the depressive-like behavior in the tail suspension and sucrose preference tests induced by LPS [57]. Besides, CBD also presented antidepressant-like effects in either naïve $[26,32,58]$ or disease animal models, such as learned helplessness model and olfactory bulbectomy models $[47,59]$. We submitted the animals to the OF test, since mobility reduction is an acute well-established characteristic of LPS administration, and is also associated with the prolonged immobility time in the forced swimming [60-62]. Despite observing the previously reported changes in mobility, CBD did not influence the total distance travelled in both saline and LPS treated animals. Florensa-Zanuy et al. also found no effect in CBD $30 \mathrm{mg} / \mathrm{kg}$ pretreatment in the open field in the depression model induced by LPS [57].

The LPS-induced SB model is a validated and widely used inflammatory model of depression, in which the activation of the immune system, with the recruitment of different leukocytes and induction of cytokines synthesis, are associated with the behavioral changes. Similarly, MDD is also characterized by an increased production and interaction of several cytokines simultaneously [63, 64].

Here, we found that CBD showed different effects depending on the brain region. In the brain, the main source of cytokines is the microglia, which present a heterogeneous population, with differences in cell number, molecular signature and functionality $[65,66]$. Furthermore, it is well known that the neurons also present subpopulations along the brain, which releases different neurotransmitters and, consequently, induce different microglial responses to stimuli [67]. For example, the microglia population from the hippocampus, an area characterized as a neurogenic zone, is different in number and functionality of the microglia from the other areas [65], and the importance of regional differences in microglia have also been reported in the SB model. CD11 and CX3CR1, two microglial markers, were increased in the hippocampus of animals treated with LPS in comparison with the controls, but no difference was found in the frontal cortex [68]. There was an increase in hippocampal IL-1 $\beta$ levels following a peripheral $E$. coli administration, but no difference in other regions such as the PFC and the hypothalamus [69]. Taken together, these differences might explain the differences found in the CBD effects in the cytokines levels between all regions evaluated in our study.

Although CBD increased pro-inflammatory cytokines both in the hippocampus and PFC of saline-treated animals, and also in the PFC from animals treated with CBD $3 \mathrm{mg} /$ $\mathrm{kg}$, it is important to evaluate the magnitude of this increase. For example, LPS and monophosphoryl lipid A (MPLA) are both capable of binding TLR4 and inducing proinflammatory cytokines release [70]. However, due to the difference in the magnitude of the cytokines levels [70], MPLA and LPS induce different effects in the brain, since MPLA can present neuroprotective effects in different conditions, while LPS does not [71, 72]. Finally, it is worth noting that IL-4 was also increased by CBD in saline-treated mice. This is an important observation, since despite may having antiand proinflammatory effects [73, 74], different studies have shown that this IL-4 modulates microglia activity and has neuroprotective effects [75-77].

Regarding the effects on the neurotrophic factors, CBD showed the same pattern of response in both the hippocampus and in the PFC. As discussed above, microglia presents subpopulations along the different brain areas [65]. In the hippocampus, these cells are an important source of 
neurotrophic factors that contribute to neurogenesis [78]. Interestingly, it has been shown that LPS activates microglia and induces neurotrophic factors release [62, 79-82]. However, in our model, CBD pretreatment might have prevented LPS-induced microglia activation, which could explain why the cannabinoid prevented the increase of the evaluated neurotrophic factors and cytokines levels in the hippocampus. Besides, a previous report showed that $\mathrm{CBD}$, at the dose of $30 \mathrm{mg} / \mathrm{kg}$, presented an antidepressant-like effect in tail suspension test and decreased the neurogenesis [83].

In our model, LPS increased NGF in the hippocampus, an effect that was prevented by CBD. Although studies that evaluated the effect of CBD on NGF are scarce, it is possible that the prevention of cytokines production, such as IL-6, could reduce the production of this neurotrophic factor [84]. However, this point should be further investigated in future studies.

The present study indicates IL- 6 as an important biochemical mediator for the behavioral findings, since it is increased in animals submitted to the MDD model. Although CBD failed to completely prevent this increase, the cytokine levels in SB group also do not differ from control levels. As previously discussed, IL-6 plays a critical role as a modulator and amplifier of inflammatory signaling, stimulating cytokine synthesis and recruitment of cells involved in the immune response [85]. Moreover, both the intrathecal administration of high doses of IL- 6 and the increased expression of its receptors induce increased immobility time in FST [86]. Florensa-Zanuy et al. also pretreated the animals with CBD $30 \mathrm{mg} / \mathrm{kg}$ and induced a depressive-like behavior by LPS $0.83 \mathrm{mg} / \mathrm{kg}$ administration. Similarly, they found an increase in IL-6 levels in the brain, as well in the plasma. However, in their work, CBD pretreatment prevented this increase [57]. The discrepancies in this result could be explained by the different timepoint of the cytokines analysis. In fact, the peak of IL-6 levels occurs $3 \mathrm{~h}$ after the LPS injection [16]. In this sense, we evaluated the IL-6 levels closer of the peak than Florensa-Zanuy et al., which could mask the CBD effect. Therefore, it is possible to assume that IL-6 is involved in the depressive-like behavior, which was observed herein.

Several inflammatory mediators are possibly changed in MDD, as previously reported $[10,11]$. Furthermore, the increase in cytokines levels $[13,14]$ was correlated with the severity of the disorder [11], while the treatment with the classical SSRI antidepressants reduced their levels [87]. Although CBD has a multifactorial molecular profile, the CBD's mechanism of action in MDD context is not well elucidate yet [88]. Most studies focused on the involvement of the 5-HT pathway in the antidepressant-like effects of CBD $[25,32,59,89]$. Here, we showed the possibility of the involvement of the CBD's anti-inflammatory properties in its antidepressant-like effects. In this sense, other CBD's molecular targets such as PPAR $\gamma$, TRP receptors and GPR55 could also has a relevant role in the neuroprotective effects of CBD, since these targets acts in inflammatory pathways [90]. For example, PPAR $\gamma$ participates of the modulation of $\mathrm{NF}-\kappa \mathrm{B}$, inhibiting some cytokines such as IL-6, IL- $1 \beta$ and TNF- $\alpha$ [91]. On the other hand, GPR55 KO mice present an increase in IL-4, IL-10, and IFN- $\gamma$ levels [92]. In fact, Florensa-Zanuy et al. [57] demonstrated that CBD $30 \mathrm{mg} / \mathrm{kg}$ pretreatment decreased IL- 6 in the brain of LPS-stimulated mice, as well as reduced PPAR $\gamma$ and NF- $\mathrm{kB}$ activation, but had no effect in TNF- $\alpha$ levels.

Although there is an intricate crosstalk between PPAR $\gamma$ and NF- $\mathrm{KB}[93,94]$, it is difficult to speculate how a drug that activates or inhibits these transcription factors may alter the production of inflammatory mediators, since other pathways may also be affected. In addition, transcription factors differently regulate the expression of inflammatory mediators depending on the time and condition. For example, PPAR $\gamma$ activation may decrease $[95,96]$ or increase [97-99] IL-1 $\beta$ or IL-6 depending on the model. It has been shown that PPAR $\gamma$ downregulates IL- 6 in the acute phase of a model of cerebral ischemia, but not later, since this cytokine has either protective or deleterious roles in this condition [100]. Thus, the effect of CBD on cytokines should not be interpreted as a sole modulation of PPAR $\gamma /$ NF- $\kappa B$ pathways.

This study has some limitations. Although the results were obtained in an inflammatory model of depression, MDD is a multifactorial disease. Thus, different animal models are required to better understand not only its pathophysiology, but also the pharmacological effects of CBD. In addition, this work did not determine neither the potential cells responsible for the production of the cytokines, nor whether these inflammatory mediators have a peripheral or central origin.

In conclusion, CBD prevented the impaired behavior induced by an inflammatory stimulus, commonly used to evaluate depressive-like and sickness behavior. Moreover, CBD differently regulated cytokines and neurotrophins. These are important findings, since they extend the previous findings of the literature that showed antidepressantlike effects of CBD in other models of depression. The mechanisms that mediate these pharmacological effects of CBD should be investigated in future studies.

Supplementary Information The online version contains supplementary material available at https://doi.org/10.1007/s43440-021-00301-8.

Acknowledgements Since 2016, science in Brazil has been under attack with consecutives annual budget cuts. Recently, in 2019, with the new administration it was added denialism and obscurantism on a daily basis. CAPES, a federal agency, is currently cutting funds to graduate programs. $\mathrm{CNPq}$ has not launched any calls for basic research proposals 
for the last 2 years and is also cutting tens of hundreds of scholarships. Brazil is currently dismantling research groups and facilities due to lack of funding. Fortunately, a few congressmen and congresswomen, like Mrs. Beatriz Cerqueira (PT-MG), understand the importance of science to a nation and provide financial support directly from the House of Representatives. This article was written under distress due to the coronavirus pandemic and threats against Democracy and Science in Brazil.

Author contributions HJR and ACPdO led the development of the research question and study design. HJR obtained the funding. PALT, PMQB and MCMS produced the first draft of this manuscript. Material preparation, data collection and analysis were performed by PALT, TCSB, ASM, ELMV, PMQB, MCMS, FAM, AP and ACPdO. All authors provided critical review and final approval of the manuscript. The corresponding author attests that all listed authors meet authorship criteria.

Funding This work was funded by resources from Fundação de Amparo à Pesquisa do Estado de Minas Gerais (FAPEMIG) and Conselho Nacional de Desenvolvimento Científico e Tecnológico (CNPq-protocol number 310347/2018-1).

Availability of data and material The specifications of materials or protocols utilized in this study are available on request to the corresponding author. Requests to access the datasets should be directed to the corresponding author. The manuscript's guarantor affirms that the manuscript is an honest, accurate, and transparent account of the study being reported.

\section{Declarations}

Conflict of interest The authors declare that there are no conflicts of interest.

Ethics approval All the procedures used in this study were institutionally approved under protocol number $78 / 2014$ by the Ethic Committee on Animal Use of Federal University of Minas Gerais.

\section{References}

1. Mrazek DA, Hornberger JC, Altar CA, Degtiar I. A review of the clinical, economic, and societal burden of treatment-resistant depression: 1996-2013. Psychiatr Serv. 2014;65:977-87. https:// doi.org/10.1176/appi.ps.201300059.

2. WHO I Depression and Other Common Mental Disorders. https:// www.who.int/mental_health/management/depression/preva lence_global_health_estimates/en/. Accessed 7 June 2021.

3. Hutin Y, Kitler ME, Dore GJ, Perz JF, Armstrong GL, Dusheiko $\mathrm{G}$, et al. Global burden of disease (GBD) for hepatitis C. J Clin Pharmacol. 2004;44:20-9. https://doi.org/10.1177/0091270003 258669.

4. Greden JF. The burden of disease for treatment-resistant depression. J Clin Psychiatry. 2001;62:26-31.

5. Mitchell AJ, Vaze A, Rao S. Clinical diagnosis of depression in primary care: a meta-analysis. Lancet. 2009;374:609-19. https:// doi.org/10.1016/S0140-6736(09)60879-5.

6. Bares M, Brunovsky M, Kopecek M, Novak T, Stopkova P, Kozeny $\mathrm{J}$, et al. Early reduction in prefrontal theta QEEG cordance value predicts response to venlafaxine treatment in patients with resistant depressive disorder. Eur Psychiatry. 2008;23:350 5. https://doi.org/10.1016/j.eurpsy.2008.03.001.
7. Fava M. A comparison of mirtazapine and nortriptyline following two consecutive failed medication treatments for depressed outpatients: a STAR*D report. Am J Psychiatry. 2006;163:1161. https://doi.org/10.1176/appi.ajp.163.7.1161.

8. Nemeroff CB. Prevalence and management of treatment-resistant depression. J Clin Psychiatry. 2007;68:17-25.

9. Nierenberg AA, DeCecco LM. Definitions of antidepressant treatment response, remission, nonresponse, partial response, and other relevant outcomes: a focus on treatment-resistant depression. J Clin Psychiatry. 2001;62:5-9.

10. Jones KA, Thomsen C. The role of the innate immune system in psychiatric disorders. Mol Cell Neurosci. 2013;53:52-62. https:// doi.org/10.1016/j.men.2012.10.002.

11. Müller N, Myint AM, Schwarz MJ. Inflammatory biomarkers and depression. Neurotox Res. 2011;19:308-18. https://doi.org/ 10.1007/s12640-010-9210-2.

12. Boorman E, Zajkowska Z, Ahmed R, Pariante CM, Zunszain PA. Crosstalk between endocannabinoid and immune systems: a potential dysregulation in depression? Psychopharmacology. 2016;233:1591-604. https://doi.org/10.1007/ s00213-015-4105-9.

13. Dowlati Y, Herrmann N, Swardfager W, Liu H, Sham L, Reim EK, et al. A meta-analysis of cytokines in major depression. Biol Psychiatry. 2010;67:446-57. https://doi.org/10.1016/j.biopsych. 2009.09.033.

14. Liu Y, Ho RCM, Mak A. Interleukin (IL)-6, tumour necrosis factor alpha (TNF- $\alpha$ ) and soluble interleukin-2 receptors (sIL-2R) are elevated in patients with major depressive disorder: a metaanalysis and meta-regression. J Affect Disord. 2012;139:230-9. https://doi.org/10.1016/j.jad.2011.08.003.

15. Schedlowski M, Engler H, Grigoleit JS. Endotoxin-induced experimental systemic inflammation in humans: a model to disentangle immune-to-brain communication. Brain Behav Immun. 2014;35:1-8. https://doi.org/10.1016/j.bbi.2013.09.015.

16. Lasselin J, Schedlowski M, Karshikoff B, Engler H, Lekander M, Konsman JP. Comparison of bacterial lipopolysaccharideinduced sickness behavior in rodents and humans: relevance for symptoms of anxiety and depression. Neurosci Biobehav Rev. 2020;115:15-24. https://doi.org/10.1016/j.neubiorev.2020.05. 001.

17. Dantzer R, O'Connor JC, Freund GG, Johnson RW, Kelley KW. From inflammation to sickness and depression: when the immune system subjugates the brain. Nat Rev Neurosci. 2008;9:46-56. https://doi.org/10.1038/nrn2297.

18. Machado Bergamaschi M, Helena Costa Queiroz R, Waldo Zuardi A, Alexandre S. Crippa J. Safety and side effects of cannabidiol, a Cannabis sativa constituent. Curr Drug Saf. 2011;6:237-49. https://doi.org/10.2174/157488611798280924.

19. Hudson R, Renard J, Norris C, Rushlow WJ, Laviolette SR. Cannabidiol counteracts the psychotropic side-effects of $8-9$ tetrahydrocannabinol in the ventral hippocampus through bidirectional control of ERK1-2 phosphorylation. J Neurosci. 2019;39:8762-77. https://doi.org/10.1523/JNEUROSCI.070819.2019.

20. de Castro Medeiros D, Cota VR, Oliveira ACP, Moreira FA, Moraes MFD. The endocannabinoid system activation as a neural network desynchronizing mediator for seizure suppression. Front Behav Neurosci. 2020;14:213. https://doi.org/10.3389/ fnbeh.2020.603245.

21. Laprairie RB, Bagher AM, Kelly MEM, Denovan-Wright EM. Cannabidiol is a negative allosteric modulator of the cannabinoid CB1 receptor. Br J Pharmacol. 2015;172:4790-805. https://doi. org/10.1111/bph.13250.

22. Long LE, Chesworth R, Huang XF, McGregor IS, Arnold JC, Karl T. A behavioural comparison of acute and chronic 
9-tetrahydrocannabinol and cannabidiol in C57BL/6JArc mice. Int J Neuropsychopharmacol. 2010;13:861-76. https://doi.org/ 10.1017/S1461145709990605.

23. McPartland JM, Duncan M, Di Marzo V, Pertwee RG. Are cannabidiol and $\Delta$ 9-tetrahydrocannabivarin negative modulators of the endocannabinoid system? A systematic review. Br J Pharmacol. 2015;172:737-53. https://doi.org/10.1111/bph.12944.

24. Russo EB, Burnett A, Hall B, Parker KK. Agonistic properties of cannabidiol at 5-HT1a receptors. Neurochem Res. 2005;30:1037-43. https://doi.org/10.1007/s11064-005-6978-1.

25. Sartim AG, Guimarães FS, Joca SRL. Antidepressant-like effect of cannabidiol injection into the ventral medial prefrontal cortex-possible involvement of 5-HT1A and CB1 receptors. Behav Brain Res. 2016;303:218-27. https://doi.org/10.1016/j.bbr.2016. 01.033 .

26. Bisogno T, Hanuš L, De Petrocellis L, Tchilibon S, Ponde DE, Brandi I, et al. Molecular targets for cannabidiol and its synthetic analogues: effect on vanilloid VR1 receptors and on the cellular uptake and enzymatic hydrolysis of anandamide. Br J Pharmacol. 2001;134:845-52. https://doi.org/10.1038/sj.bjp.0704327.

27. Campos AC, Moreira FA, Gomes FV, del Bel EA, Guimarães FS. Multiple mechanisms involved in the large-spectrum therapeutic potential of cannabidiol in psychiatric disorders. Philos Trans $\mathrm{R}$ Soc B Biol Sci. 2012;367:3364-78. https://doi.org/10.1098/rstb. 2011.0389.

28. Pandolfo P, Silveirinha V, Dos S-R, Venance L, Ledent C, Takahashi RN, et al. Cannabinoids inhibit the synaptic uptake of adenosine and dopamine in the rat and mouse striatum. Eur J Pharmacol. 2011;655:38-45. https://doi.org/10.1016/j.ejphar. 2011.01.013.

29. Ibeas Bih C, Chen T, Nunn AVW, Bazelot M, Dallas M, Whalley BJ. Molecular targets of cannabidiol in neurological disorders. Neurotherapeutics. 2015;12:699-730. https://doi.org/10.1007/ s13311-015-0377-3.

30. Stasiulewicz A, Znajdek K, Grudzień M, Pawiński T, Sulkowska JI. A guide to targeting the endocannabinoid system in drug design. Int J Mol Sci. 2020. https://doi.org/10.3390/ijms210827 78.

31. Hillard C, Liu Q. Endocannabinoid signaling in the etiology and treatment of major depressive illness. Curr Pharm Des. 2014;20:3795-811. https://doi.org/10.2174/138161281131966 60735 .

32. Zanelati TV, Biojone C, Moreira FA, Guimarães FS, Joca SRL. Antidepressant-like effects of cannabidiol in mice: possible involvement of 5-HT 1A receptors. Br J Pharmacol. 2010;159:122-8. https://doi.org/10.1111/j.1476-5381.2009. 00521.x.

33. Burstein S. Cannabidiol (CBD) and its analogs: a review of their effects on inflammation. Bioorgan Med Chem. 2015;23:1377-85. https://doi.org/10.1016/j.bmc.2015.01.059.

34. Castillo A, Tolón MR, Fernández-Ruiz J, Romero J, MartinezOrgado J. The neuroprotective effect of cannabidiol in an in vitro model of newborn hypoxic-ischemic brain damage in mice is mediated by CB2 and adenosine receptors. Neurobiol Dis. 2010;37:434-40. https://doi.org/10.1016/j.nbd.2009.10.023.

35. Karmaus PWF, Wagner JG, Harkema JR, Kaminski NE, Kaplan BLF. Cannabidiol (CBD) enhances lipopolysaccharide (LPS)induced pulmonary inflammation in C57BL/6 mice. J Immunotoxicol. 2013;10:321-8. https://doi.org/10.3109/1547691X.2012. 741628.

36. Anil SM, Shalev N, Vinayaka AC, Nadarajan S, Namdar D, Belausov E, et al. Cannabis compounds exhibit anti-inflammatory activity in vitro in COVID-19-related inflammation in lung epithelial cells and pro-inflammatory activity in macrophages. Sci Rep. 2021;11:1462. https://doi.org/10.1038/ s41598-021-81049-2.
37. Chen W, Kaplan BLF, Pike ST, Topper LA, Lichorobiec NR, Simmons SO, et al. Magnitude of stimulation dictates the cannabinoid-mediated differential T cell response to HIV gp120. J Leukoc Biol. 2012;92:1093-102. https://doi.org/10.1189/jlb. 0212082 .

38. Muthumalage T, Rahman I. Cannabidiol differentially regulates basal and LPS-induced inflammatory responses in macrophages, lung epithelial cells, and fibroblasts. Toxicol Appl Pharmacol. 2019;382: 114713. https://doi.org/10.1016/j.taap.2019.114713.

39. Britch SC, Goodman AG, Wiley JL, Pondelick AM, Craft RM. Antinociceptive and immune effects of delta-9-tetrahydrocannabinol or cannabidiol in male versus female rats with persistent inflammatory pain. J Pharmacol Exp Ther. 2020;373:416-28. https://doi.org/10.1124/jpet.119.263319.

40. Wickens RA, Ver Donck L, MacKenzie AB, Bailey SJ. Repeated daily administration of increasing doses of lipopolysaccharide provides a model of sustained inflammation-induced depressivelike behaviour in mice that is independent of the NLRP3 inflammasome. Behav Brain Res. 2018;352:99-108. https://doi.org/10. 1016/j.bbr.2017.07.041.

41. O'Connor JC, Lawson MA, André C, Moreau M, Lestage J, Castanon N, et al. Lipopolysaccharide-induced depressive-like behavior is mediated by indoleamine 2,3-dioxygenase activation in mice. Mol Psychiatry. 2009;14:511-22. https://doi.org/ 10.1038/sj.mp.4002148.

42. Dantzer R. Cytokine, sickness behavior, and depression. Immunol Allergy Clin North Am. 2009;29:247-64. https://doi.org/10. 1016/j.iac.2009.02.002.

43. Maes M, Berk M, Goehler L, Song C, Anderson G, Gałecki $\mathrm{P}$, et al. Depression and sickness behavior are Janus-faced responses to shared inflammatory pathways. BMC Med. 2012;10:1-19. https://doi.org/10.1186/1741-7015-10-66.

44. Horita JKHA, Da Silva MCM, Ferrari CZ, Vieira ELM, Moreira FA, De Oliveira ACP, et al. Evaluation of brain cytokines and the level of brain-derived neurotrophic factor in an inflammatory model of depression. NeuroImmunoModulation. 2021;27:87-96. https://doi.org/10.1159/000511181.

45. Biesmans S, Meert TF, Bouwknecht JA, Acton PD, Davoodi N, De Haes P, et al. Systemic immune activation leads to neuroinflammation and sickness behavior in mice. Mediat Inflamm. 2013. https://doi.org/10.1155/2013/271359.

46. Porsolt RD, Le Pichon M, Jalfre M. Depression: a new animal model sensitive to antidepressant treatments [27]. Nature. 1977;266:730-2. https://doi.org/10.1038/266730a0.

47. Sales AJ, Fogaça MV, Sartim AG, Pereira VS, Wegener G, Guimarães FS, et al. Cannabidiol induces rapid and sustained antidepressant-like effects through increased BDNF signaling and synaptogenesis in the prefrontal cortex. Mol Neurobiol. 2019;56:1070-81. https://doi.org/10.1007/s12035-018-1143-4.

48. Fogaça MV, Campos AC, Coelho LD, Duman RS, Guimarães FS. The anxiolytic effects of cannabidiol in chronically stressed mice are mediated by the endocannabinoid system: role of neurogenesis and dendritic remodeling. Neuropharmacology. 2018;135:22-33. https://doi.org/10.1016/j.neuropharm.2018. 03.001 .

49. Campos AC, Ortega Z, Palazuelos J, Fogaça MV, Aguiar DC, Díaz-Alonso J, et al. The anxiolytic effect of cannabidiol on chronically stressed mice depends on hippocampal neurogenesis: involvement of the endocannabinoid system. Int J Neuropsychopharmacol. 2013;16:1407-19. https://doi.org/10. 1017/S1461145712001502.

50. Köhler CA, Freitas TH, Stubbs B, Maes M, Solmi M, Veronese $\mathrm{N}$, et al. Peripheral alterations in cytokine and chemokine levels after antidepressant drug treatment for major depressive disorder: systematic review and meta-analysis. Mol 
Neurobiol. 2018;55:4195-206. https://doi.org/10.1007/ s12035-017-0632-1.

51. Nestler EJ, Barrot M, DiLeone RJ, Eisch AJ, Gold SJ, Monteggia LM. Neurobiology of depression. Neuron. 2002;34:13-25. https://doi.org/10.1016/S0896-6273(02)00653-0.

52. Krishnan V, Nestler EJ. The molecular neurobiology of depression. Nature. 2008;455:894-902. https://doi.org/10.1038/natur e07455.

53. Yankelevitch-Yahav R, Franko M, Huly A, Doron R. The forced swim test as a model of depressive-like behavior. J Vis Exp. 2015;2015:52587. https://doi.org/10.3791/52587.

54. Petit-Demouliere B, Chenu F, Bourin M. Forced swimming test in mice: a review of antidepressant activity. Psychopharmacology. 2005;177:245-55. https://doi.org/10.1007/ s00213-004-2048-7.

55. Matsuo N. Behavioral profiles of three C57BL/6 substrains. Front Behav Neurosci. 2010;4:29. https://doi.org/10.3389/fnbeh.2010. 00029 .

56. Commons KG, Cholanians AB, Babb JA, Ehlinger DG. The rodent forced swim test measures stress-coping strategy, not depression-like behavior. ACS Chem Neurosci. 2017;8:955-60. https://doi.org/10.1021/acschemneuro.7b00042.

57. Florensa-Zanuy E, Garro-Martínez E, Adell A, Castro E, Díaz Á, Pazos Á, et al. Cannabidiol antidepressant-like effect in the lipopolysaccharide model in mice: modulation of inflammatory pathways. Biochem Pharmacol. 2021;185: 114433. https://doi. org/10.1016/j.bcp.2021.114433.

58. Réus GZ, Stringari RB, Ribeiro KF, Luft T, Abelaira HM, Fries GR, et al. Administration of cannabidiol and imipramine induces antidepressant-like effects in the forced swimming test and increases brain-derived neurotrophic factor levels in the rat amygdala. Acta Neuropsychiatr. 2011;23:241-824. https://doi. org/10.1111/j.1601-5215.2011.00579.x.

59. Linge R, Jiménez-Sánchez L, Campa L, Pilar-Cuéllar F, Vidal $\mathrm{R}$, Pazos A, et al. Cannabidiol induces rapid-acting antidepressant-like effects and enhances cortical 5-HT/glutamate neurotransmission: role of 5-HT1A receptors. Neuropharmacology. 2016;103:16-26. https://doi.org/10.1016/j.neuropharm.2015.12. 017.

60. de Paiva VN, Lima SNP, Fernandes MM, Soncini R, Andrade CAF, Giusti-Paiva A. Prostaglandins mediate depressive-like behaviour induced by endotoxin in mice. Behav Brain Res. 2010;215:146-51. https://doi.org/10.1016/j.bbr.2010.07.015.

61. Zhang R, Wang J, Hu Y, Lu X, Jiang B, Zhang W, et al. Pifithrin- $\mu$ attenuates acute sickness response to lipopolysaccharide in C57BL/6J mice. Pharmacology. 2016;97:245-50. https:// doi.org/10.1159/000444187.

62. Savage JC, St-Pierre MK, Hui CW, Tremblay ME. Microglial ultrastructure in the hippocampus of a lipopolysaccharideinduced sickness mouse model. Front Neurosci. 2019. https:// doi.org/10.3389/fnins.2019.01340.

63. De La Garza R. Endotoxin- or pro-inflammatory cytokineinduced sickness behavior as an animal model of depression: focus on anhedonia. Neurosci Biobehav Rev. 2005;29:761-70. https://doi.org/10.1016/j.neubiorev.2005.03.016.

64. Himmerich H, Patsalos O, Lichtblau N, Ibrahim MAA, Dalton B. Cytokine research in depression: principles, challenges, and open questions. Front Psychiatry. 2019;10:30. https://doi.org/10. 3389/fpsyt.2019.00030.

65. Tan YL, Yuan Y, Tian L. Microglial regional heterogeneity and its role in the brain. Mol Psychiatry. 2020;25:351-67. https://doi. org/10.1038/s41380-019-0609-8.

66. Miller SJ. Astrocyte heterogeneity in the adult central nervous system. Front Cell Neurosci. 2018;12:15. https://doi.org/10.3389/ fncel.2018.00401.
67. Lee M. Neurotransmitters and microglial-mediated neuroinflammation. Curr Protein Pept Sci. 2013;14:21-32. https://doi.org/10. 2174/1389203711314010005.

68. Rossetti AC, Paladini MS, Trepci A, Mallien A, Riva MA, Gass $P$, et al. Differential neuroinflammatory response in male and female mice: a role for BDNF. Front Mol Neurosci. 2019;12:166. https://doi.org/10.3389/fnmol.2019.00166.

69. Barrientos RM, Frank MG, Hein AM, Higgins EA, Watkins LR, Rudy JW, et al. Time course of hippocampal IL-1 $\beta$ and memory consolidation impairments in aging rats following peripheral infection. Brain Behav Immun. 2009;23:46-54. https://doi.org/ 10.1016/j.bbi.2008.07.002.

70. Luan L, Patil NK, Guo Y, Hernandez A, Bohannon JK, Fensterheim BA, et al. Comparative transcriptome profiles of human blood in response to the toll-like receptor 4 ligands lipopolysaccharide and monophosphoryl lipid A. Sci Rep. 2017;7:1-16. https://doi.org/10.1038/srep40050.

71. Venezia S, Refolo V, Polissidis A, Stefanis L, Wenning GK, Stefanova N. Toll-like receptor 4 stimulation with monophosphoryl lipid A ameliorates motor deficits and nigral neurodegeneration triggered by extraneuronal $\alpha$-synucleinopathy. Mol Neurodegener. 2017. https://doi.org/10.1186/s13024-017-0195-7.

72. Michaud JP, Hallé M, Lampron A, Thériault P, Préfontaine P, Filali M, et al. Toll-like receptor 4 stimulation with the detoxified ligand monophosphoryl lipid A improves Alzheimer's diseaserelated pathology. Proc Natl Acad Sci USA. 2013;110:1941-6. https://doi.org/10.1073/pnas.1215165110.

73. Gadani SP, Cronk JC, Norris GT, Kipnis J. IL-4 in the brain: a cytokine to remember. J Immunol. 2012;189:4213-9. https://doi. org/10.4049/jimmunol.1202246.

74. Michelucci A, Heurtaux T, Grandbarbe L, Morga E, Heuschling P. Characterization of the microglial phenotype under specific pro-inflammatory and anti-inflammatory conditions: effects of oligomeric and fibrillar amyloid- $\beta$. J Neuroimmunol. 2009;210:3-12. https://doi.org/10.1016/j.jneuroim.2009.02.003.

75. Rossi C, Cusimano M, Zambito M, Finardi A, Capotondo A, Garcia-Manteiga JM, et al. Interleukin 4 modulates microglia homeostasis and attenuates the early slowly progressive phase of amyotrophic lateral sclerosis article. Cell Death Dis. 2018;9:116. https://doi.org/10.1038/s41419-018-0288-4.

76. Chen X, Zhang J, Song Y, Yang P, Yang Y, Huang Z, et al. Deficiency of anti-inflammatory cytokine IL-4 leads to neural hyperexcitability and aggravates cerebral ischemia-reperfusion injury. Acta Pharm Sin B. 2020;10:1634-45. https://doi.org/10.1016/j. apsb.2020.05.002.

77. Lively S, Schlichter LC. Microglia responses to pro-inflammatory stimuli (LPS, IFN $\gamma+\mathrm{TNF} \alpha$ ) and reprogramming by resolving cytokines (IL-4, IL-10). Front Cell Neurosci. 2018;12:215. https://doi.org/10.3389/fncel.2018.00215.

78. Araki T, Ikegaya Y, Koyama R. The effects of microglia- and astrocyte-derived factors on neurogenesis in health and disease. Eur J Neurosci. 2020;00:1-22. https://doi.org/10.1111/ejn.14969.

79. Zhang K, Wu S, Li Z, Zhou J. MicroRNA-211/BDNF axis regulates LPS-induced proliferation of normal human astrocyte through PI3K/AKT pathway. Biosci Rep. 2017;37:20170755. https://doi.org/10.1042/BSR20170755.

80. Kirsten TB, Casarin RC, Bernardi MM, Felicio LF. Pioglitazone abolishes cognition impairments as well as BDNF and neurotensin disturbances in a rat model of autism. Biol Open. 2019. https://doi.org/10.1242/bio.041327.

81. Miwa T, Furukawa S, Nakajima K, Furukawa Y, Kohsaka S. Lipopolysaccharide enhances synthesis of brain-derived neurotrophic factor in cultured rat microgila. J Neurosci Res. 1997;50:1023-9. https://doi.org/10.1002/(SICI)10974547(19971215)50:6\%3c1023::AID-JNR13\%3e3.0.CO;2-5. 
82. Zhang X, Zhu LB, He JH, Zhang HQ, Ji SY, Zhang CN, et al. Paroxetine suppresses reactive microglia-mediated but not lipopolysaccharide-induced inflammatory responses in primary astrocytes. J Neuroinflammation. 2020. https://doi.org/10.1186/ s12974-020-1712-0.

83. Schiavon AP, Bonato JM, Milani H, Guimarães FS, Weffort de Oliveira RM. Influence of single and repeated cannabidiol administration on emotional behavior and markers of cell proliferation and neurogenesis in non-stressed mice. Prog NeuroPsychopharmacol Biol Psychiatry. 2016;64:27-34. https://doi. org/10.1016/j.pnpbp.2015.06.017.

84. Minnone G, De Benedetti F, Bracci-Laudiero L. NGF and its receptors in the regulation of inflammatory response. Int $\mathrm{J}$ Mol Sci. 2017. https://doi.org/10.3390/ijms18051028.

85. Kishimoto T. Interleukin-6: discovery of a pleiotropic cytokine. Arthritis Res Ther. 2006. https://doi.org/10.1186/ar1916.

86. Sukoff Rizzo SJ, Neal SJ, Hughes ZA, Beyna M, RosenzweigLipson S, Moss SJ, et al. Evidence for sustained elevation of IL-6 in the CNS as a key contributor of depressive-like phenotypes. Transl Psychiatry. 2012;2: e199. https://doi.org/10.1038/tp.2012. 120.

87. Hannestad J, Dellagioia N, Bloch M. The effect of antidepressant medication treatment on serum levels of inflammatory cytokines: a meta-analysis. Neuropsychopharmacology. 2011;36:2452-9. https://doi.org/10.1038/npp.2011.132.

88. Sales AJ, Guimarães FS, Joca SRL. CBD modulates DNA methylation in the prefrontal cortex and hippocampus of mice exposed to forced swim. Behav Brain Res. 2020;388: 112627. https://doi. org/10.1016/j.bbr.2020.112627.

89. Sales AJ, Crestani CC, Guimarães FS, Joca SRL. Antidepressant-like effect induced by cannabidiol is dependent on brain serotonin levels. Prog Neuro-Psychopharmacol Biol Psychiatry. 2018;86:255-61. https://doi.org/10.1016/j.pnpbp.2018.06.002.

90. García-Gutiérrez MS, Navarrete F, Gasparyan A, AustrichOlivares A, Sala F, Manzanares J. Cannabidiol: a potential new alternative for the treatment of anxiety, depression, and psychotic disorders. Biomolecules. 2020;10:1-34. https://doi.org/10.3390/ biom10111575.

91. Vallée A, Lecarpentier Y, Guillevin R, Vallée JN. Effects of cannabidiol interactions with Wnt/ $\beta$-catenin pathway and PPAR $\gamma$ on oxidative stress and neuroinflammation in Alzheimer's disease. Acta Biochim Biophys Sin. 2017;49:853-66. https://doi.org/10. 1093/abbs/gmx073.

92. Staton PC, Hatcher JP, Walker DJ, Morrison AD, Shapland EM, Hughes JP, et al. The putative cannabinoid receptor GPR55 plays a role in mechanical hyperalgesia associated with inflammatory and neuropathic pain. Pain. 2008;139:225-36. https://doi.org/10. 1016/j.pain.2008.04.006.

93. De Bosscher K, Vanden Berghe W, Haegeman G. Cross-talk between nuclear receptors and nuclear factor $\mathrm{\kappa B}$. Oncogene. 2006;25:6868-86. https://doi.org/10.1038/sj.onc.1209935.

94. Scirpo R, Fiorotto R, Villani A, Amenduni M, Spirli C, Strazzabosco M. Stimulation of nuclear receptor peroxisome proliferator-activated receptor- $\gamma$ limits NF- $\mathrm{BB}$-dependent inflammation in mouse cystic fibrosis biliary epithelium. Hepatology. 2015;62:1551-62. https://doi.org/10.1002/hep.28000.

95. Heming M, Gran S, Jauch SL, Fischer-Riepe L, Russo A, Klotz $\mathrm{L}$, et al. Peroxisome proliferator-activated receptor- $\gamma$ modulates the response of macrophages to lipopolysaccharide and glucocorticoids. Front Immunol. 2018;9:1. https://doi.org/10.3389/fimmu. 2018.00893.

96. Wang LH, Yang XY, Zhang X, Huang J, Hou J, Li J, et al. Transcriptional inactivation of STAT3 by PPAR $\gamma$ suppresses IL-6-responsive multiple myeloma cells. Immunity. 2004;20:205-18. https://doi.org/10.1016/S1074-7613(04)00030-5.

97. Weber KJ, Sauer M, He L, Tycksen E, Kalugotla G, Razani B, et al. PPAR $\gamma$ deficiency suppresses the release of IL- $1 \beta$ and IL- $1 \alpha$ in macrophages via a type 1 IFN-dependent mechanism. J Immunol. 2018;201:2054-69. https://doi.org/10.4049/jimmunol. 1800224.

98. Glatz T, Stöck I, Nguyen-Ngoc M, Gohlke P, Herdegen T, Culman J, et al. Peroxisome-proliferator-activated receptors $\gamma$ and peroxisome-proliferator-activated receptors $\beta / \delta$ and the regulation of interleukin 1 receptor antagonist expression by pioglitazone in ischaemic brain. J Hypertens. 2010;28:1488-97. https:// doi.org/10.1097/HJH.0b013e3283396e4e.

99. Wanichkul T, Han S, Huang RP, Sidell N. Cytokine regulation by peroxisome proliferator-activated receptor gamma in human endometrial cells. Fertil Steril. 2003;79:763-9. https://doi.org/ 10.1016/S0015-0282(02)04835-5.

100. Patzer A, Zhao Y, Stöck I, Gohlke P, Herdegen T, Culman J. Peroxisome proliferator-activated receptors $\gamma(\operatorname{PPAR} \gamma)$ differently modulate the interleukin- 6 expression in the peri-infarct cortical tissue in the acute and delayed phases of cerebral ischaemia. Eur J Neurosci. 2008;28:1786-94. https://doi.org/10.1111/j.14609568.2008.06478.x.

Publisher's Note Springer Nature remains neutral with regard to jurisdictional claims in published maps and institutional affiliations. 